\title{
国別・産業部門別マクロ経済データを用いた 自然災害と経済成長の関連性に関する実証分析
}

\author{
福田 大輔 1 遠藤 壮一郎 2 \\ 1正会員 東京工業大学准教授 環境・社会理工学院 土木・環境工学系 \\ （三152-85524 東京都目黒区大岡山2-12-1） \\ E-mail: fukuda@plan.cv.titech.ac.jp \\ 2非会員 日本貿易振興機構 ものづくり産業部 環境・インフラ課 \\ （ 个107-6006 東京都港区赤坂1-12-32） \\ Email: soichiro_endo@jetro.go.jp
}

\begin{abstract}
本研究では，自然災害と国の経済成長の関係性に関する実証分析を行った。具体的には，自然災害統計 EM-DATとマクロ経済データWDIの各国統計情報を統合した国別パネルデータを用いて, 自然災害の生起 又はその規模が各国の経済全体あるいは産業部門別の経済成長に及ぼす影響を把握するための計量経済モ デルを構築した。システム一般化積率法を用いたパラメータ推定の結果，自然災害はGDPに対して統計的 に有意ではないものの概ね弱い正の影響があること，産業部門によって自然災害がその成長にもたらす影 響の方向が有意に異なることなどが確認された。また，既存の理論研究より示唆される自然災害の生産性 効果と本研究の推定結果とが矛盾していないことも確認された.
\end{abstract}

Key Words : natural disaster, economic growth, econometric analysis, panel data, productivity effect

\section{1. はじめに}

自然災害による経済被害は世界的に見て増加傾向にあ り，将来的に，気候変動などに起因する被害の増加等も 懸念されている. 自然災害が発生すると, 生産設備やイ ンフラストラクチャーなどのストックに大きな影響が及 ぶと共に，供給側に大きな影響（生産力の低下など）が 生じる。我が国を例にとっても，1995年の阪神淡路大震 災，2004年の中越沖地震，さらには2011年3月の東日本 大震災によって多くの生産拠点や交通インフラが被災し, 国民経済も大きな影響を受けた。それぞれの震災による 資本ストックの直接被害額は約 9 兆 6 千億円（国土庁）， 約 3 兆円（新潟県），約 16 兆 9 千億円（内閣府）之甚大 なものであったことが報告されている ${ }^{1)}$.

経済成長と自然災害の関連性については，異なる因果 方向を仮定した二つのアプローチが存在する．第一のア プローチはもともとの経済発展状況により被災の度合い がどう変化するのかを追求する立場であり，第二のアプ ローチは自然災害の発生がその後の経済成長にどのよう な影響を与えるのかを追求する立場である ${ }^{2)}$. 特に近年, 後者の立場から，マクロ統計データを用いて自然災害が 経済成長に及ぼす影響に関する実証研究が進展している.
この第二のアプローチの研究の潮流は，さらに二つに 大別される。一つは，短・中期的（1～5 年程度）な影 響に関するもので，主に自然災害が GDP 成長率に及ぼ す影響を検証している。具体的には，災害発生前後にお ける GDP, インフレ率, 投資量, 部門別生産量等の変 化の検証 ${ }^{3)}$, 自然災害のみならず戦争・紛争なども含め た外的ショックの影響の検証 ${ }^{4}$, 各国の制度や政策の相 違が自然災害に及ぼす影響の検証 ${ }^{5}$ ，産業部門及び自然 災害の種類を細分化した上での検証 のなどが行われてい る（表-1）。実証分析の結果に関して，定型化した事実 と呼べるものは現時点では見当たらないものの，自然災 害が経済に負の影響を及ぼすのはあくまでも災害発生直 後であり，そのような非常時が終了して以降については 必ずしも負の影響が続くとは限らない7)という共通見解 は，広く得られていると考えられる。

一方，もう一つの研究の潮流として，長期的（10〜30 年程度）な影響に関するものが挙げられる。具体的には， 災害発生頻度が長期の経済成長や物的資本あるいは人的 資本の蓄積に及ぼす影響の分析 ${ }^{8)}$, 多様な自然災害指標 の影響の分析 ${ }^{9)}$ ，災害発生頻度と技術移転の容易性の関 連性の検証 ${ }^{10)}$ などが行われている（表-2）。そこでは, 甚大な災害によって旧式の技術が失われることで新たな 
技術進歩が起こり，生産性が向上寸ることによって経済 成長が促進される可能性も指摘されている77,13).

このように，自然災害が経済成長に対して短・中・長 期に渡って影響を与える可能性があることが既往研究か ら示唆されているものの，それらの関係性に関する統一 的な見解を得るには至っていない，特に，既往研究の多 くは一国全体の経済活動に着目したもの，すなわち，国 全体の一人当たり GDP 成長率を被説明変数として分析 したものが大半である，現実には，例えば，農業を中心 とする発展途上国では, 自然災害の影響を受けやすく, 洪水や干ばつによって生産量が大きく変動する可能性な どが考えられる. 他方, 工業やサービス業等の部門が卓 越する先進国では，インフラストラクチャーや生産設備 に影響が及ぶことで，その生産量変化（成長）に影響が 生じる場合も考えられる.

以上の問題意識のもと, 本研究では自然災害がマクロ 経済成長に及ぼす影響に関する実証分析を行う。具体的 には，まず，国単位のマクロ経済データと自然災害デー

表-1 短・中期的な影響を対象とした既往研究

\begin{tabular}{|c|c|c|}
\hline 研究 & 被説明変数 & 説明変数と推定弾性值等 \\
\hline Albala-Betrand" & GDP成長率 & 全災害 : +0.40\% \\
\hline Raddatz $^{4}$ & GDP成長率 & 気候変動：-2.0\% \\
\hline $\mathrm{Noy}^{5}$ & GDP成長率 & $\begin{array}{l}\text { 経済被害額(直接被害額) : }+1.3 \% \\
\text { 影響人口 :- }-9.7 \%\end{array}$ \\
\hline Loayza et al. ${ }^{6}$ & GDP成長率 & $\begin{array}{l}\text { 干ばつ : }-0.606 \% \\
\text { 洪水 : }-0.996 \% \\
\text { 地震・嵐 : 有意でない }\end{array}$ \\
\hline Fomby et al. ${ }^{11)}$ & GDP成長率 & $\begin{array}{l}\text { 干ばつ : }-1.5 \% \\
\text { 洪水 : }+0.2 \% \\
\text { 地震 : }+0.5 \% \\
\end{array}$ \\
\hline
\end{tabular}

表-2 長期的な影響を対象とした既往研究

\begin{tabular}{|c|c|c|}
\hline 研究 & 被説明変数 & 説明変数と推定弾性值等 \\
\hline $\begin{array}{l}\text { Skidmore and } \\
\text { Toya }^{8}\end{array}$ & GDP成長率 & $\begin{array}{l}\text { 気候関連災害 : }+0.42 \% \\
\text { 地理関連災害 : }-0.32 \%\end{array}$ \\
\hline $\begin{array}{l}\text { Noy and } \\
\text { Aekkanush" }\end{array}$ & GDP成長率 & $\begin{array}{l}\text { 死亡者数人口：-6.58（係数） } \\
\text { 経済被害額/GDP : 有意でない }\end{array}$ \\
\hline Raddatz $^{12}$ & GDP 水準 & $\begin{array}{l}\text { 気候関連災害 : - }-0.6 \% \\
\text { 地理関連属性 : 有意でない } \\
\text { その他属性 : }+2.0 \%\end{array}$ \\
\hline
\end{tabular}

タを統合して最新のパネルデータベースを構築する. 次 に，新古典派の標準的な経済成長モデルを理論的基礎と した最新の実証研究である Loayza et al. ${ }^{9}$ を拡張すると共 に，多様な自然災害指標を構築した上で，経済成長の規 定要因を推計するための計量経済モデルを新たに構築す る. その際, モデルのパラメータ推定では, 変数間の内 生性に配慮した適切な推定方法を適用寸ることで, 推定 量の一致性（標本数を大きくするにつれて推定值が真值 に確率収束する性質）を保証する。さらに実証分析では, 国全体の経済成長と自然災害の影響の関係の夕に着目寸 るのではなく，産業部門別に見た被影響度の違い，自然 災害のタイプ別に見た経済成長一の影響度の違い, 開発 途上国や小国等の各国の基本特性による自然災害の影響 度の違い等についても検討し, 包括的な検証を行う。

\section{2. データ}

本研究では, まず，マクロ経済指標に関するパネルデ 一タとして, 世界銀行の World Development Indicator $(\mathrm{WDI})^{14)}$ を用いる. 次に, 自然災害統計データに関して は, Centre for Research on the Epidemiology of Disasters（ルー ヴァン・カトリック大学, ベルギー）が整備している Emergency Disasters Database (EM-DAT) ${ }^{15}$ を用いる。 EMDAT は世界の様々な種類の自然災害の統計情報を広範 かつ包括的に扱っているオープンデータである.

構築した経済・災害統合データベースは，国によって データ久損も見られる. できるだけ多くの国を含められ るよう配慮し, 分析対象期間は 1980 年から 2010 年まで の 30 年間とする. その結果, 以降で詳述する各計量経 済モデルにおいて分析対象となる国数は最大で 85 力国 となった．またその際，本研究の主眼が自然災害の中期 的な影響を検証することに呼応し，一期 5 年として 6 期 分の (不完備) パネルデータを構築する. 5 年程度の期 間を一期とすることで，災害発生直後の短期的な経済混 乱の影響を緩和し，自然災害の影響も含めた一国のマク 口経済状況が当該期間内で構造的に安定している[1]こと を仮定できることが, 先行研究のでも確認されている.

表-3 自然災害に関する基本統計（1980～2010年）

\begin{tabular}{lccccc}
\hline \multicolumn{1}{c}{ 諸量 } & 干ばつ & 洪水 & 嵐 & 地震 & 計 \\
\hline \hline 影響人口の平均 $($ 人) & 6022881 & 1234658 & 428082 & 140840 & 7826461 \\
\hline 推定被害額平均 (USMillion\$) & 533.45 & 348.52 & 477.91 & 1076.98 & 2436.86 \\
\hline 災害生起数 [影響人口あり] & 314 & 2262 & 1606 & 730 & 4912 \\
\hline 災害生起数 [経済被害額あり] & 147 & 1077 & 1310 & 318 & 2852 \\
\hline 災害生起数 [全体] & 496 & 2768 & 2617 & 828 & 6709 \\
\hline ※影響人口 : 緊急時において, 迅速な救助を必要とする人々の数. たとえば, 救助とは食事, 水, 住居, 衛 \\
生や医療行為のことを指す. 死亡者数 : 災害時に, 死亡が確認された, もしくは行方不明となったまたは死 \\
亡と見なされた人口. 推定被害額 : 災害の直接被害額（たとえば, インフラ, 款物や住宅の破壊など) と間 \\
接被害額（歳入の減少，失業の増加や市場の不安定など）の両方を当時の金額（US\$) で推定したもの.
\end{tabular}




\section{(1) 自然災害の定義}

EM-DAT における「自然災害」の定義は，以下のいず れかの条件を満たす状況とされている.

1. 10 人以上の人々が亡くなっていること.

2. 100 人以上の人々が影響を受けていること .

3. 被災地域で緊急事態宣言が発令されていること.

4. 国際的な援助を求めていること.

また，EM-DATにおいて，自然災害は，気候関連，水 文関連，気象関連，地理関連の4カテゴリーに分けられ ている. 本研究では, このカテゴリーに呼応して, 主要 な自然災害である干ばつ，洪水，嵐，地震の4つの災害 タイプに焦点を当てて分析を行う。これらの災害による 被害は, 統計データの中でも大きな割合を占めており， 1980 2002年の期間の総推定被害額の内訳は，12\%が地 震， $40 \%$ が洪水，37\%が嵐となっている ${ }^{10}$. 干ばつは農 業に大きな影響を及ぼすと考えられる，表-3に各自然災 害の基本統計量を示す．地震のような局地的災害は影響 人口が少ない反面，一回の発生で大きな経済被害が生じ る傾向があることが分かる．また，洪水は非常に広範囲 の人々に影響を与えるものの, 一回の発生当たりの経済 被害額は比較的小さいものであることも確認される.

\section{(2) 自然災害指標の構築}

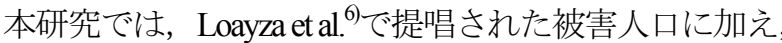
災害生起数, 影響人口，推定経済被害額等の情報に基づ いた計 4 種類の自然災害指標を新たに構築する.

\section{a) 被害人口}

$$
N D \_d_{i, t}=\log \left(\frac{1}{5} \sum_{j} \frac{\text { People }_{\text {hurt }}{ }_{i, t, j}}{\text { Population }_{i, t}}\right)
$$

People hurt $\equiv$ People affected $\times 0.3+$ People killed (2) ここで， $i$ :国， $t$ : 時点（5 年を 1 期とする）， $j:$ 災害タイ プ, People affected: 影響人口, People killed: 死亡者 数, Population: 人口である. 式(2)の影響人口の重み 0.3 は $\mathrm{IMF}^{17)}$ の算定に基づく，被害人口を用いることで災害 頻度と大きさの両方を分析に組み込むことが可能となる． また，影響人口と死亡者数を同時に含めた指標とするこ とで被災した受けた全ての人を考慮することができる.

\section{b) 影響人口}

緊急時に迅速な救助を必要とする人の数である影響人 口（People affected）に特化した指標を構築する.

$$
N D \_p_{i, t}=\log \left(\frac{1}{5} \sum_{j} \frac{{\text { People } \text { affected }_{i, t, j}}_{\text {Population }_{i, t}}}{\text { Pola }}\right)
$$

\section{c) 災害生起数}

災害の種類にかかわらず，当該国における総災害生起 数に着目した指標を構筑する.
$N D \_$num $_{i, t}=\log \left(\frac{1}{5} \sum_{j}\right.$ Number of disaster dit,,$\left.j\right)$

ここで, Number of disasters: 各タイプ $(j)$ 毎の災害生 起数である.

\section{d) 推定被害額}

$$
N D \_e c o n_{i, t}=\log \left(\frac{1}{5} \sum_{j} \frac{\text { Estimated damage }_{i, t, j}}{G D P_{i, t}}\right)
$$

ここで，Estimated damage: 推定経済被害額，GDP: 一 人当たり GDP である. 推定被害額は，直接被害と間接 被害の両方を推定した結果を用いたもので，この指標も 災害の頻度と大きさの両方を考慮することができる．し かし表-3に示したとおり，災害の種類によって影響人口 と推定被害額の大きさの平均值は異なるため, 両指標の 特性は異なる。

\section{(3) マクロ経済データ}

分析で用いる各国のマクロ経済変数を表-4にまとめる. 自然災害が経済成長に及ぼす影響をバイアスが極力生じ ることなく推定するためのコントロール変数として, 教 育水準，金融深度，政府負担，貿易開放度，交易条件成 長度，インフレーションなどの変数を用いる．なお，4. で詳述するとおり，投資量については，他の変数とは別 扱いとする. 前述の通り 5 年を 1 期とした分析を行うた め, データは 5 年毎に平均化を行っている.

\section{3. 計量経済モデル}

\section{(1) モデルの特定化}

各国の経済成長の規定要因は多様であり，インフレ率 や投資のような経済要因の他に, 政治体制や法制度, 地

\begin{tabular}{|c|c|}
\hline モデル内の変数名 & WDIにおける指標の定義 \\
\hline 経済成長率 & $\begin{array}{l}\text { ・ 一人あたり実質 GDP 成長率 } \\
\text { ・部門 (農業, 工業, サービス) 毎の } \\
\text { 一人あたり実質付加価値成長率 } \\
\text { [いずれも } 2000 \text { 年 US ドル換算·対数差分值 }]\end{array}$ \\
\hline 教育水準 & 中等学校就学率 (対人口・対数値) \\
\hline 金融深度 & 民間信用比率（対 GDP・対数值） \\
\hline 政府負担 & 政府最終消費支出比率（対 GDP · 対数值） \\
\hline 貿易開放度 & 輸出入額比率（対 GDP・対数值） \\
\hline 交易条件成長度 & 純商品交易条件指数（対数差分值） \\
\hline インフレーション & 消費者物価指数上昇率（刘数値） \\
\hline 投資量 & 固定資本形成比率 (対 GDP ・\%值) \\
\hline
\end{tabular}
理的・言語的な要素などといった多様な要因が影響を及 ぼす可能性が指摘されている ${ }^{18)}$. 本研究では既往研究 9 
を参考に，基本的な新古典派成長モデル（一人あたり GDP 成長率を，初期時点での一人あたり GDP 及び幾つ かの変数によって回帰する, いわゆる Barro Regression ${ }^{19)}$ ) をパネルデータに対応できるように拡張した上で, 経済 成長に関する国別のマクロ計量経済モデルの基本形を以 下のように特定化する.

$y_{i, t}-y_{i, t-1}=\alpha y_{i, t-1}+\beta X_{i, t}+\gamma^{\prime} Z_{i, t}+\mu_{t}+\varphi_{i}+\varepsilon_{i t}$

ここで, $y_{i, t}$ : 生産量 (対数值),$X_{i, t}$ : 投資量, $Z_{i, t}$ : 政策 や制度に係るコントロール変数ベクトル， $\mu_{t}$ : 観測不可 能な時系列効果項, $\varphi_{i}$ : 観測不可能な国別固定効果項, $\varepsilon_{i t}$ : 攪乱項, $\alpha, \beta, \gamma:$ 未知パラメータ (ベクトル) である. $y_{i, t}$ に関しては，一国の経済全体を対象とする場合には 一人当たり実質 GDP の対数值を用いる．もしくは，産 業部門（農業, 工業, サービス）別に分析を行う場合に は，一人当たり実質付加価值額の対数值を用いる.

式(6)の左辺は経済成長率そのものを表しており，右 辺にはその説明要因として, 生産量の期首值, 投資量, 当該国の制度や制度等を表すコントロール変数が与えら れている.さらに，パネルデータの利用を念頭に，時系 列効果及び国別の固定効果も考慮されている.

上述した基本形には自然災害の影響が含まれていない Durlauf et al. ${ }^{18)}$ では，自然災害が技術革新と投資に影響を 与える可能性も示唆されているが，本研究では，自然災 害の経済成長率への影響に焦点を当てるため, 以下のよ うにモデルを拡張する.

$$
\begin{aligned}
y_{i, t}-y_{i, t-1}= & \alpha y_{i, t-1}+\beta X_{i, t}+\gamma^{\prime} Z_{i, t}+\theta N D_{i, t} \\
& +\mu_{t}+\varphi_{i}+\varepsilon_{i t}
\end{aligned}
$$

ここで， $N D_{i, t}$ : 自然災害指標（先述の $N D \_d_{i, t}, N D \_p_{i, t}$, $N D \_n u m_{i, t}, N D \_e c o n_{i, t}$ のいずれか一つ)， $\theta$ : 未知パラ メータである.

上記の拡張モデルを用いることで，パネルデータの特 性を十分に踏まえて自然災害の直接的影響を推定するこ とができる.

\section{(2) パラメータ推定方法}

式(7) は右辺に時系列効果項と国別の固定効果項が含 まれており，標準的な最小二乗（Ordinary Least Squares: OLS）推定などではパラメータの一致推定量を得ること ができない. さらに，投資量やコントロール変数として 利用される諸変数も, 一定程度まで内生性を有している 可能性があり ${ }^{18)}$ ，被説明変数と説明変数の間で相関が生 じることが大いに考えられる.

そこで本研究では，パネルデータに操作変数を適用す ることでパラメータの一致推定量を得ることを可能とす るシステム一般化積率法 (System Generalized-method-of-moments: System-GMM) ${ }^{20), 21)}$ を適用する. システム一般化積
率法では，適切なラグ変数を操作変数として用いること で内生性バイアスに対処することができる，また，自然 災害の高次の影響（間接被害や復興事業などより長期に 及ぶ経済的影響等）を除外した上で自然災害のマクロ経 済への直接的影響を推計することが可能となる．推定方 法や検定方法の詳細については付録を参照されたい.

\section{4. 推定結果と考察}

\section{（1）基本モデル（被害人ロ）}

被害人口を自然災害指標に用いて GDP 及び部門毎の 経済成長に及ぼす影響を推定した結果（基本モデル）を 表-5に示す．全てのモデル推定において，生産量期首值 を除き同じ説明変数を導入した. 表中の $\mathrm{t}$ 值は全て “ロ バスト $\mathrm{t}$ 值”（付録参照）である.また，推定量の一致 性に関する検定として, Arellano-Bond検定（1次及び2次 の自己相関 $[\mathrm{AR}(1), \mathrm{AR}(2)]$ に関する検定 $)^{22)}$ と Hansen過剩 識別制限検定（操作変数の妥当性に関する検定 $)^{23}$ を行 った，以降，各表中の $\mathrm{z}$ は $\mathrm{Z}$ 值を，PはP值をそれぞれ 表す. 表-5に示した全ての結果では，両検定共に有意水 準 5\%で各帰無仮説が棄却されており, 操作変数を用い たシステム一般化積率法によって推定されたモデルが支 持された結果となっている.

表-5の最左列（被説明变数: GDP成長率）より, 自然 災害（被害人口）が経済成長に及ぼす影響は正となって いるもののその影響度は小さく (0.068)，統計的有意 性も強くないことが分かる，一方，表-5の右三列より経 済部門毎の結果を見ると, 自然災害が農業部門の成長に 有意な負の影響（-0.648）を与える一方で，工業・サー ビス部門に対しては有意な正の影響を与えていることが 確認される．農業部門は自然環境からの影響を受けやす く, 自然災害による農業生産施設の被害がその成長率に も大きな負の影響を与えることが推察される。さらに GDP・工業部門・サービス部門とは異なり，農業部門の 成長に対しては投資量も有意な負の影響を与えているこ とが確認される. 通常, 投資は経済成長を促進するとさ れているが 19)，農業はその他の経済部門とは違った成長 メカニズムを持っている可能性が示唆される.

次に，工業部門とサービス部門を比べると，自然災害 が成長にもたらす正の影響は工業部門の方がやや大きい （推定值 : 0.376 $>0.228 ）$.一般に，工業部門はサービス 部門に比べて，設備投資が生産量の水準に与える影響が 大きいと言われているが ${ }^{18)}$ ，このように自然災害が経済 成長に与える影響に両部門間で差が生じているという事 実は，理論研究 ${ }^{24)}$,25)が示唆している「復興期間における 技術進歩が経済成長を促す」という “自然災害の生産性 効果” 仮説とも整合するものである.ここで Okuyama ${ }^{24)}$ 
表-5 被害人口を自然災害指標として用いた場合のモデル推定結果

\begin{tabular}{|c|c|c|c|c|c|c|c|c|}
\hline \multirow[b]{2}{*}{ 説明変数 } & \multicolumn{2}{|c|}{ GDP成長率 } & \multicolumn{2}{|c|}{ 農業部門成長率 } & \multicolumn{2}{|c|}{ 工業部門成長率 } & \multicolumn{2}{|c|}{ サービス部門成長率 } \\
\hline & 推定值 & $\mathrm{t}$ 值 & 推定值 & $\mathrm{t}$ 值 & 推定值 & $\mathrm{t}$ 值 & 推定值 & $\mathrm{t}$ 值 \\
\hline 生産量期首值 & 0.486 & 1.44 & -2.905 & -5.73 & -0.151 & -0.34 & 0.996 & 3.49 \\
\hline 投資量 & 2.749 & 4.77 & -2.204 & -3.7 & 3.609 & 3.48 & 4.982 & 8.11 \\
\hline 自然災害（被害人口） & 0.068 & 1.19 & -0.648 & -10.87 & 0.376 & 3.73 & 0.228 & 3.05 \\
\hline 交易条件成長度 & 0.236 & 5.13 & 0.040 & 1.47 & 0.482 & 7.63 & 0.160 & 8.03 \\
\hline インフレーション & 0.717 & 1.16 & 1.871 & 2.7 & 0.283 & 0.24 & -3.721 & -7.36 \\
\hline 政府負担 & -5.107 & -8.77 & -2.064 & -3.51 & -7.544 & -8.71 & -4.138 & -5.34 \\
\hline 教育水淮 & -0.836 & -1.36 & 0.389 & 2.1 & -0.721 & -1.15 & -0.344 & -1.01 \\
\hline 貿易開放度 & -0.552 & -1.18 & 0.992 & 1.95 & 0.306 & 0.44 & -0.150 & -0.41 \\
\hline 金融深度 & 0.613 & 1.78 & 0.329 & 1.06 & 1.129 & 2.42 & -0.668 & -2.81 \\
\hline 定数項 & 4.083 & 1.13 & 7.686 & 1.27 & 11.284 & 1.75 & 14.852 & 3.77 \\
\hline 観測数 & 166 & & 156 & & 157 & & 166 & \\
\hline グループ数（国数） & 72 & & 67 & & 68 & & 72 & \\
\hline 操作変数の数 & 47 & & 47 & & 47 & & 47 & \\
\hline Arellano-Bond 検定 [AR(1)] & $z=-1.73$ & $P=0.084$ & $z=-1.65$ & $P=0.099$ & $z=-1.93$ & $P=0.054$ & $z=-1.91$ & $P=0.056$ \\
\hline Arellano-Bond 検定 [AR(2)] & $z=1.30$ & $P=0.193$ & $z=-1.49$ & $P=0.137$ & $z=0.59$ & $P=0.558$ & $z=1.20$ & $P=0.230$ \\
\hline Hansen検定 & & $P=0.444$ & & $P=0.547$ & & $P=0.720$ & & $P=0.272$ \\
\hline
\end{tabular}

表-6 影響人口を自然災害指標として用いた場合のモデル推定結果

\begin{tabular}{|c|c|c|c|c|c|c|c|c|}
\hline \multirow[b]{2}{*}{ 説明変数 } & \multicolumn{2}{|c|}{ GDP成長率 } & \multicolumn{2}{|c|}{ 農業部門成長率 } & \multicolumn{2}{|c|}{ 工業部門成長率 } & \multicolumn{2}{|c|}{ サービス部門成長率 } \\
\hline & 推定值 & $\mathrm{t}$ 值 & 推定値 & $\mathrm{t}$ 值 & 推定值 & $\mathrm{t}$ 值 & 推定値 & t值 \\
\hline 生産量期首值 & 0.494 & 2.04 & -2.94 & -6.0 & 0.093 & 0.25 & 0.709 & 2.18 \\
\hline 投資量 & 3.753 & 6.68 & -2.16 & -2.73 & 3.634 & 3.4 & 3.514 & 4.1 \\
\hline 自然災害（影響人口） & -0.089 & -1.65 & -0.24 & -2.62 & 0.231 & 2.3 & 0.089 & 0.77 \\
\hline 交易条件成長度 & 0.202 & 4.94 & 0.09 & 1.95 & 0.325 & 4.91 & 0.089 & 1.99 \\
\hline インフレーション & 1.086 & 1.48 & 2.84 & 2.72 & -1.333 & -1.36 & -2.970 & -3.98 \\
\hline 政府負担 & -4.574 & -7.68 & -2.44 & -3.47 & -5.355 & -5.04 & 4.056 & -5.53 \\
\hline 教育水準 & -0.650 & -1.69 & 0.54 & 1.59 & 0.017 & 0.03 & 0.054 & 0.11 \\
\hline 貿易開放度 & -0.703 & -1.83 & -0.04 & -0.07 & -0.474 & -0.81 & -0.757 & -1.56 \\
\hline 金融深度 & 0.320 & 1.07 & -0.10 & -0.26 & 0.586 & 1.49 & -0.345 & -0.8 \\
\hline 定数項 & -2.143 & -0.61 & 12.48 & 1.88 & 12.095 & 2.26 & 16.217 & 3.28 \\
\hline 観測数 & 198 & & 186 & & 187 & & 182 & \\
\hline グループ数（国数） & 81 & & 75 & & 77 & & 74 & \\
\hline 操作変数の数 & 47 & & 47 & & 47 & & 47 & \\
\hline Arellano-Bond 検定 [AR(1)] & $z=-2.30$ & $P=0.022$ & $z=-2.10$ & $P=0.035$ & $z=-1.93$ & $P=0.054$ & $z=-2.14$ & $P=0.033$ \\
\hline Arellano-Bond 検定 [AR(2)] & $z=-0.16$ & $P=0.874$ & $z=-1.47$ & $P=0.141$ & $z=-0.36$ & $P=0.722$ & $z=1.33$ & $P=0.184$ \\
\hline Hansen 検定 & & $P=0.333$ & & $P=0.611$ & & $P=0.396$ & & $P=0.325$ \\
\hline
\end{tabular}

では，標準的な Solow-Swanモデルを拡張して経済成長と 自然災害被害の関係性を分析し，実証研究 3),5) 一゙確認さ れている災害発生後の中期的な経済成長は復興期間にお ける技術進歩によって主に説明されると結論づけている. また HallegatteandDumas ${ }^{25}$ では，自然災害で破壊された資 本部分に，復興期間における最新の技術水準を持つ生産 資本が導入されることで全体の生産性が向上するメカニ ズムを記述し，その影響を分析している．本実証分析に よる部門毎の推定結果，特に工業部門の結果は，自然災 害の生産性効果仮説に反しないものであると考えられる.

\section{(2) 自然災害指標の相違による影響}

次に 2. (2)で定義した他の自然災害指標を説明変数と して用い, パラメータ推定を行った結果を表-6〜8 に示
す.このうち，影響人口（表-6）および災害生起数（表 -7）を用いた結果に関しては，多くの場合で Arellan-Bond 検定 $[\mathrm{AR}(1)]$ の帰無仮説が有意水準 5\%で棄却されてお り, ラグ変数間の一階の自己相関の影響を十分には考慮 できていない可能性があることに予め留意されたい.

被災人口を用いた結果（表-5）と影響人口を用いた結 果（表-6）を比較すると，GDP 成長率に関しては自然災 害の影響の方向（推定值：0.068 v.s. -0.089）が異なってい る. また，サービス部門の成長に対しては，影響人口が 及ぼす影響は有意でない（ $(\mathfrak{t} 0.77 ）$ こも確認される. 一方，影響人口を用いた場合でも，農業部門では自然災 害が有意な負の影響（t=2.62）を，また，工業部門では 有意な正の影響（ $(\mathrm{t}=2.3 ）$ を与ていることが分かる.

災害生起数を用いた結果（表-7）では，サービス部門 
表-7 災害生起数を自然災害指標として用いた場合のモデル推定結果

\begin{tabular}{|c|c|c|c|c|c|c|c|c|}
\hline \multirow[b]{2}{*}{ 説明変数 } & \multicolumn{2}{|c|}{ GDP成長率 } & \multicolumn{2}{|c|}{ 農業部門成長率 } & \multicolumn{2}{|c|}{ 工業部門成長率 } & \multicolumn{2}{|c|}{ サービス部門成長率 } \\
\hline & 推定值 & $\mathrm{t}$ 值 & 推定值 & $\mathrm{t}$ 值 & 推定值 & $\mathrm{t}$ 值 & 推定値 & $\mathrm{t}$ 值 \\
\hline 生産量期首值 & 0.498 & 1.91 & -2.835 & -5.25 & -0.067 & -0.21 & 0.965 & 2.7 \\
\hline 投資量 & 5.326 & 8.08 & -1.382 & -1.98 & 6.675 & 6.31 & 3.064 & 3.59 \\
\hline 自然災害（災害生起数） & 0.066 & 1.48 & -0.021 & -0.3 & -0.003 & -0.03 & 0.184 & 4.78 \\
\hline 交易条件成長度 & 0.127 & 4.41 & 0.031 & 0.9 & 0.269 & 5.82 & 0.117 & 5.39 \\
\hline インフレーション & 2.931 & 3.64 & 4.750 & 4.82 & -1.844 & -1.78 & -0.642 & -0.74 \\
\hline 政府負担 & -2.118 & -3.84 & -0.580 & -0.87 & -5.896 & -6.53 & -3.195 & -5.23 \\
\hline 教育水淮 & -1.054 & -3.35 & 0.807 & 2.52 & 0.120 & 0.26 & -1.193 & -2.5 \\
\hline 貿易開放度 & -1.077 & -2.53 & 0.187 & 0.35 & -0.489 & -0.73 & -1.099 & -2.55 \\
\hline 金融深度 & 0.372 & 1.52 & -0.161 & -0.53 & -0.092 & -0.22 & 0.333 & 1.09 \\
\hline 定数項 & -18.585 & -4.29 & -4.162 & -0.61 & 8.518 & 1.35 & 5.104 & 1.18 \\
\hline 観測数 & 221 & & 208 & & 207 & & 202 & \\
\hline グループ数（国数） & 85 & & 78 & & 80 & & 77 & \\
\hline 操作変数の数 & 47 & & 47 & & 47 & & 47 & \\
\hline Arellano-Bond 検定 [AR(1)] & $z=-2.13$ & $P=0.033$ & $z=-2.74$ & $P=0.006$ & $z=-2.23$ & $P=0.026$ & $z=-2.59$ & $P=0.010$ \\
\hline Arellano-Bond検定 [AR(2)] & $z=-0.76$ & $P=0.449$ & $z=1.46$ & $P=0.144$ & $z=1.22$ & $P=0.221$ & $z=1.37$ & $P=0.170$ \\
\hline Hansen検定 & & $P=0.594$ & & $P=0.384$ & & $P=0.526$ & & $P=0.347$ \\
\hline
\end{tabular}

表-8 推定被害額を自然災害指標として用いた場合のモデル推定結果

\begin{tabular}{|c|c|c|c|c|c|c|c|c|}
\hline \multirow{2}{*}{ 説明変数 $\quad$ 被説明変数 } & \multicolumn{2}{|c|}{ GDP成長率 } & \multicolumn{2}{|c|}{ 農業部門成長率 } & \multicolumn{2}{|c|}{ 工業部門成長率 } & \multicolumn{2}{|c|}{ サービス部門成長率 } \\
\hline & 推定値 & t値 & 推定値 & $\mathrm{t}$ 値 & 推定値 & $\mathrm{t}$ 值 & 推定値 & t值 \\
\hline 生産量期首値 & 0.854 & 3.42 & -0.374 & -1.33 & 0.384 & 0.75 & 0.693 & 1.82 \\
\hline 投資量 & 4.625 & 6.91 & -0.258 & -0.26 & 2.862 & 2.08 & 6.823 & 6.4 \\
\hline 自然災害（推定被害額） & -0.045 & -0.54 & -0.163 & -2.83 & -0.039 & -0.63 & 0.051 & 0.76 \\
\hline 交易条件成長度 & 0.233 & 8.74 & 0.060 & 1.15 & 0.209 & 3.03 & 0.138 & 4.55 \\
\hline インフレーション & -2.888 & -6.48 & -1.173 & -2.42 & -3.378 & -2.76 & -4.289 & -7.04 \\
\hline 政府負担 & -4.506 & -6.55 & -2.272 & -3.31 & -7.098 & -6.71 & -2.337 & -3.21 \\
\hline 教育水準 & -1.594 & -3.15 & 0.302 & 0.58 & -1.066 & -1.7 & -0.548 & -1.24 \\
\hline 貿易開放度 & -1.044 & -2.28 & -0.410 & -0.96 & -0.613 & -0.8 & -2.089 & -3.98 \\
\hline 金融深度 & -0.265 & -0.71 & -0.114 & -0.48 & 0.025 & 0.05 & -0.761 & -1.63 \\
\hline 定数項 & 18.464 & 8.07 & 14.488 & 3.53 & 32.021 & 3.0 & 16.995 & 7.24 \\
\hline 観測数 & 138 & & 131 & & 131 & & 128 & \\
\hline グループ数（国数） & 65 & & 60 & & 62 & & 59 & \\
\hline 操作変数の数 & 53 & & 53 & & 53 & & 53 & \\
\hline Arellano-Bond検定 [AR(1)] & $z=-1.35$ & $P=0.177$ & $z=-1.20$ & $P=0.230$ & $z=-1.51$ & $P=0.132$ & $z=-1.41$ & $P=0.159$ \\
\hline Arellano-Bond 検定 [AR(2)] & $z=-0.94$ & $P=0.348$ & $z=-1.05$ & $P=0.295$ & $z=-1.45$ & $P=0.147$ & $z=-0.94$ & $P=0.346$ \\
\hline Hansen検定 & & $P=0.794$ & & $P=0.72$ & & $P=0.706$ & & $P=0.487$ \\
\hline
\end{tabular}

のみにおいて自然災害が経済成長に有意な正の影響 （t=4.78）を与えていることが確認された．災害生起数 には自然災害の発生頻度のみが反映される一方，災害の 甚大さの違いを考慮できない，すなわち，「単純に自然 災害が多いという理由だけで経済成長が促進される訳で はない」という，直感的な知見を支持する結果である.

推定被害額（表-8）に関しては，他の三種類の自然災 害指標を用いた場合とは異なり，パラメータ推定におい て内生変数として取り扱った。これは，EM-DATによる 推定被害額の内訳に，自然災害による直接被害額に加え て空間・時間的に広がる間接被害額も含まれており ${ }^{15}$, 後者の間接災害額は経済成長自体とも相関を持つ可能性 があるためである、いずれの被説明変数の場合でも， Arellano-Bond 検定, Hansen 検定双方とも帰無仮説は棄却
されず，推定方法が妥当であることは確認されている. 推定被害額は，農業部門の成長に対してのみ有意な負の 影響を与えており（t=-2.83），それ以外に対しては有意 な影響を与えていない ${ }^{[2] .}$

農業部門に関して，用いる自然災害指標の相違を横断 的に比べると, 被害人口（ （た-2.62，表-6），推定被害額（た=2.83，表-8）が農業部 門の成長に有意な負の影響を与えているが，災害生起数 は有意な影響を与えていない（表-7）。一方表-3より， 影響人口，被害人口に大きく寄与する自然災害タイプは 干ばつであることが推察される（影響人口の平均值が 4 種の災害タイプの中で最も大きいため) 。これらより， 農業部門の経済成長の差異は, 災害の種類の差異による 影響を大きく受ける可能性があることが示唆される. 
表-9 開発途上国のみを分析対象とした場合のモデル推定結果（自然災害指標 : 被害人口）

\begin{tabular}{|c|c|c|c|c|c|c|c|c|}
\hline \multirow{2}{*}{$\begin{array}{ll}\text { 被説明変数 } \\
\text { 説明変数 }\end{array}$} & \multicolumn{2}{|c|}{ GDP成長率 } & \multicolumn{2}{|c|}{ 農業部門成長率 } & \multicolumn{2}{|c|}{ 工業部門成長率 } & \multicolumn{2}{|c|}{ サービス部門成長率 } \\
\hline & 推定值 & $\mathrm{t}$ 值 & 推定值 & $\mathrm{t}$ 值 & 推定值 & $\mathrm{t}$ 值 & 推定値 & $\mathrm{t}$ 值 \\
\hline 生産量期首值 & -0.138 & -0.39 & -3.812 & -6.04 & -0.448 & -0.78 & -0.519 & -1.09 \\
\hline 投資量 & 2.217 & 3.09 & -2.088 & 4.35 & 2.468 & 2.13 & 4.534 & 8.56 \\
\hline 自然災害（被害人口） & 0.002 & 0.04 & -0.619 & -8.92 & 0.635 & 5.27 & 0.204 & 3.32 \\
\hline 交易条件成長度 & 0.180 & 5.41 & -0.070 & -2.71 & 0.279 & 5.58 & 0.098 & 3.21 \\
\hline インフレーション & 1.431 & 1.93 & 2.119 & 3.39 & -2.843 & -3.83 & -1.697 & 4.13 \\
\hline 政府負担 & -5.037 & -9.36 & 0.795 & 1.76 & -7.412 & -10.39 & -3.148 & 4.4 \\
\hline 教育水準 & -0.303 & -1.11 & 1.546 & 6.87 & 0.329 & 0.47 & 0.784 & 1.83 \\
\hline 貿易開放度 & -0.100 & -0.27 & -0.304 & -0.79 & 1.151 & 1.61 & 0.071 & 0.21 \\
\hline 金融深度 & 0.573 & 1.89 & 0.443 & 1.68 & -0.308 & -0.63 & -0.098 & -0.29 \\
\hline 定数項 & 2.686 & 0.56 & 4.515 & 0.83 & 29.771 & 5.28 & 7.450 & 2.51 \\
\hline 観測数 & 134 & & 127 & & 126 & & 125 & \\
\hline グループ数（国数） & 55 & & 53 & & 52 & & 52 & \\
\hline 操作変数の数 & 47 & & 47 & & 47 & & 47 & \\
\hline Arellano-Bond 検定 [AR(1)] & $z=-1.79$ & $P=0.073$ & $Z=-1.37$ & $P=0.172$ & $z=-1.74$ & $P=0.081$ & $z=-1.72$ & $P=0.086$ \\
\hline Arellano-Bond 検定 [AR(2)] & $z=1.08$ & $P=0.280$ & $Z=1.03$ & $P=0.305$ & $z=-0.89$ & $P=0.374$ & $z=1.28$ & $P=0.202$ \\
\hline Hansen検定 & & $P=0.464$ & & $P=0.619$ & & $P=0.626$ & & $P=0.465$ \\
\hline
\end{tabular}

表-10 非小国のみを分析対象とした場合のモデル推定結果（自然災害指標 : 被害人口）

\begin{tabular}{|c|c|c|c|c|c|c|c|c|}
\hline \multirow[b]{2}{*}{ 説明変数 } & \multicolumn{2}{|c|}{ GDP成長率 } & \multicolumn{2}{|c|}{ 農業部門成長率 } & \multicolumn{2}{|c|}{ 工業部門成長率 } & \multicolumn{2}{|c|}{$\begin{array}{c}\text { サービス部門成長 } \\
\text { 率 }\end{array}$} \\
\hline & 推定值 & $\mathrm{t}$ 值 & 推定值 & $\mathrm{t}$ 值 & 推定值 & $\mathrm{t}$ 值 & 推定值 & $\mathrm{t}$ 值 \\
\hline 生産量期首值 & 0.152 & 0.34 & -1.988 & 4.0 & -0.362 & -0.89 & -0.218 & -0.52 \\
\hline 投資量 & 3.235 & 4.62 & -6.030 & -5.72 & 5.112 & 6.4 & 6.014 & 6.63 \\
\hline 自然災害（被害人口） & 0.074 & 1.02 & -0.400 & -3.51 & 0.073 & 0.81 & 0.148 & 1.74 \\
\hline 交易条件成長度 & 0.291 & 6.9 & 0.150 & 2.46 & 0.405 & 6.79 & 0.207 & 7.71 \\
\hline インフレーション & 0.934 & 2.18 & 0.669 & 1.17 & 1.185 & 2.55 & 0.470 & 0.68 \\
\hline 政府負担 & -3.854 & 4.43 & -2.813 & -3.83 & -5.184 & 4.05 & -2.078 & -1.85 \\
\hline 教育水準 & -0.440 & -0.48 & -0.150 & -0.28 & -0.641 & -1.2 & 0.865 & 1.61 \\
\hline 貿易開放度 & -0.627 & -1.28 & 1.127 & 2.55 & -1.277 & -2.56 & -0.934 & -2.07 \\
\hline 金融深度 & 0.795 & 3.01 & 0.658 & 1.92 & 1.473 & 4.25 & 0.257 & 1.19 \\
\hline 定数項 & -1.255 & -0.28 & 24.161 & 7.53 & -0.198 & -0.04 & -10.466 & -2.02 \\
\hline 観測数 & 132 & & 128 & & 129 & & 127 & \\
\hline グループ数（国数） & 56 & & 52 & & 53 & & 51 & \\
\hline 操作変数の数 & 47 & & 47 & & 47 & & 47 & \\
\hline Arellano-Bond 検定 [AR(1)] & $z=-1.77$ & $P=0.076$ & $z=-1.50$ & $P=0.133$ & $z=-2.05$ & $P=0.040$ & $z=-1.73$ & $P=0.084$ \\
\hline Arellano-Bond 検定 [AR(2)] & $z=0.47$ & $P=0.637$ & $z=1.48$ & $P=0.138$ & $z=1.06$ & $P=0.288$ & $z=1.26$ & $P=0.206$ \\
\hline Hansen検定 & & $P=0.738$ & & $P=0.530$ & & $P=0.626$ & & $P=0.877$ \\
\hline
\end{tabular}

投資量に関しては，全ての自然災害指標の場合におい て，農業部門では有意な負の影響を，その他の部門では 有意な正の影響を経済成長に与えていることが共通して 確認される. その他の諸コントロール変数の推定結果に 関しても, 自然災害指標の相違というよりもむしろ, 被 説明変数の相違によって係数の符号や有意性が異なって いることが概ね確認できる。これらの結果より，自然災 害は経済成長に対して一定程度の頑健な影響を与える可 能性があることが示唆される. しかし，自然災害指標に よっては統計的に有意でないものもあるため, さらなる 実証分析を通じた知見の蓄積が必要である.

\section{(3) 開発途上国における自然災害の影響}

次に, 経済発展の度合いに応じて自然災害が経済成長 に及ぼす影響がどう変化するのかを把握することを企図 して，分析対象国を OECD加盟国と非加盟国とにセグメ ント分けして推定を行った。ここでは $\mathrm{OECD}$ 非加盟国を 開発途上国と見なし，それらのサンプルデータのみを用 いてパラメータ推定を行った結果を表-9に示す.

発展途上国では, 自然災害（被害人口）が GDP 成長 率に及ぼす影響がほぼゼロとなっている（推定值 : 0.002)。また，開発途上国では，GDP に対する自然災害 被害額が大きくなっている ${ }^{15}$. Hallegatte and Dumas ${ }^{25}$ では, GDP に対して自然災害による被害が大きい場合には 
GDP 成長率の平均值が小さくなることが示唆されてお り，本推定結果はその知見とも整合している，一方，農 業部門に対してはより大きな負の影響が，工業部門やサ 一ビス部門に対してはより大きな正の影響が生じている ことも確認される. 開発途上国においては，農業部門に おける自然災害の影響が先進国に比べて大きく，農業部 門の災害に対する経済脆弱性が大きいことが示唆される.

\section{（4）小国以外の国々における自然災害の影響}

次に，国の物理的あるいは経済的規模が災害脆弱性に どのような影響を与えているかを把握するために，分析 対象のサンプル国を，小国と小国でない（中・大規模の） 国とに分けて推定を行った. 小国の定義は, Mankiw et $\mathrm{al}^{26}$ ) で提唱されている1960年時点で人口が 100 万人未満と いう条件を用いた。 それら小国と見なされた国を除外し， 中・大規模国に限定して推計した結果を表-10に示す. 産業部門別の結果を見ると, 総じて自然災害の係数の絶 対值がこれまでの推定結果に比べて小さくなっているこ とが分かる．これは，小国に比べて中・大規模の国々の 方が自然災害の影響を受けにくいことを示唆している. 一方，GDP成長率に自然災害が及ぼす影響に関しては, 従来の推定結果と大きな差異が無いことも確認される.

\section{5. まとめと今後の課題}

本研究では，自然災害が経済成長に及ぼす影響につい ての計量経済分析を行った. モデルの推定結果より, 総 じて，自然災害はGDP成長率に対して多くは有意ではな いものの弱い正の影響を与えていることが確認された. 一方，自然災害の影響は，産業部門別に見るとその影響 の方向が異なっていることが確認された．具体的には, 農業部門の生産の成長に対しては, 自然災害は統計的に 有意な負の影響があること，一方，工業・サービス部門 の生産の成長に対しては有意な正の影響があることが確 認された.これらの知見は，自然災害指標として別のも のを用いた場合でも概ね同様であった（但し推定被害額 を除く）。さらに，特に工業部門において，説明変数に 投資量が含まれた上で自然災害が有意な正の影響を与え ている結果が確認されたが，これは従来の理論研究で提 唱された自然災害の生産性効果仮説とも整合する結果で あった. 最後に, 開発途上国や非小国に分析対象を絞っ た場合でも，概ね直感的に解釈可能な推定結果となった。 本研究では, 説明変数として用いしたマクロ経済指標 のデータ数に制約があり, 災害種類の詳細に分けること ができなかった．分析対象期間をより長く取る，あるい は，一期の間隔を短くとすることでデータ数を確保でき る可能性も考えられるため, 推定精度とのトレードオフ
を考えながらそのような検討を行う必要がある. また， 今回構築した計量経済モデルは，短・中期的な影響に主 眼を置いており，自然災害が長期的に経済成長に及ぼす 影響についても，今後実証事例を蓄積する必要がある.

\section{付録 パラメータ推定方法の詳細}

以降の記述は主として北村 ${ }^{27)}$, 戸堂 ${ }^{28)}$ に準拠する. 一般化積率法 (GMM) は, Hansen ${ }^{23)}$ で提案されて以 来，汎用性の高い推定手法として多くの実証研究で適用 されている. GMMは, Arellano and Bond ${ }^{22)}$ にって動的 パネルデータモデルの推定のために差分一般化積率法と して拡張された.さらに, 利用データに求められる要件 を少なくするため, Arellano and Bover ${ }^{20)}$, Blundell and Bond ${ }^{21)}$ によってシステム一般化積率法が開発された.

\section{（1）差分一般化積率法 (Difference-GMM)}

まず，式(7)から時系列効果項と国別固定効果項をキ ヤンセルアウトするために階差を取る.

$$
\begin{aligned}
y_{i, t}-y_{i, t-1}= & \alpha\left(y_{i, t-1}-y_{i, t-2}\right)+\lambda^{\prime}\left(\boldsymbol{V}_{i, t}-\boldsymbol{V}_{i, t-1}\right) \\
& +\left(\varepsilon_{i, t}-\varepsilon_{i, t-1}\right)
\end{aligned}
$$

ここで $\boldsymbol{V}_{i, t}=\left(X_{i, t}, Z^{\prime}{ }_{i, t}, N D_{i, t}\right)^{\prime}, \lambda=\left(\beta, \gamma^{\prime}, \theta\right)^{\prime}$ である 上記のモデルでも， $y_{i, t}$ に自己相関がある場合 $(\alpha \neq 0)$ には一致推定量を得ることができない.また， $\boldsymbol{V}_{i, t}$ に内 生性が存在する $\left(\varepsilon_{i, t}-\varepsilon_{i, t-1}\right.$ と $\boldsymbol{V}_{i, t}$ が相関する）場合に も一致推定量を得ることができない。ここで， $\boldsymbol{V}_{i, t}$ と $\varepsilon_{i, t}-\varepsilon_{i, t-1}$ の相関のパターンには通常次の二通りがある. 第一は, $\boldsymbol{V}_{i, t}$ が $\varepsilon_{i, t}$ およびそれ以前の $\varepsilon$ とは相関するが, それ以降の $\varepsilon$ とは相関しない場合で, この状況を従来同 様 “ $\boldsymbol{V}_{i, t}$ が内生的” という。第二に, $\boldsymbol{V}_{i, t}$ が $\varepsilon_{i, t-1}$ および それ以前の $\varepsilon$ とは相関するが, $\varepsilon_{i, t}$ およびそれ以降の $\varepsilon$ とは相関しない場合で，この状況を “ $\boldsymbol{V}_{i, t}$ が先決的” と いう. このように内生変数や先決変数が存在する場合に は, 通常の OLS は元より, 固定効果モデルや 1 階差分 式を用いても一致推定量を得ることはできない.

Arellano and Bond ${ }^{22)}$ は, $t-2$ 期の $y_{i, t-2}$ は，それより後 に決まる $\varepsilon_{i, t}-\varepsilon_{i, t-1}$ とは相関しないが, $y_{i, t-1}-y_{i, t-2}$ と は相関する性質に着目し， $y_{i, t-2}$ あるいはより大きなラ グ変数を操作変数として用いる方法を提唱した. 同様に, $\boldsymbol{V}_{i, t}$ が内生的あるいは先決的な場合でも， $\boldsymbol{V}_{i, t-2}$ あるいは より大きなラグ変数を操作変数に用いることができる.

このとき, モーメント条件は次式のように表される.

$$
\begin{aligned}
& E\left[y_{i, t-s} \bullet\left(\varepsilon_{i t}-\varepsilon_{i t-1}\right)\right]=0 \quad \forall s \geq 2 ; t=3, \ldots, T \\
& E\left[V_{i, t-s} \bullet\left(\varepsilon_{i t}-\varepsilon_{i t-1}\right)\right]=\mathbf{0} \quad \forall s \geq 2 ; t=3, \ldots, T
\end{aligned}
$$


ここで， $T$ : パネル調査期間である.このように，操作 変数を利用して,一階の差分方程式（式(8)）に対して GMM 推定を行うことを差分一般化積率法という.

差分一般化積率法において, サンプル $i$ の操作変数行 列 $\boldsymbol{Q}_{i}$ は以下のように表される（紙面の都合上，ここで は説明変数が過去の $y$ のみの場合の紹介に留める）。

$$
\boldsymbol{Q}_{i}=\left[\begin{array}{cccccccccc}
y_{i, 1} & 0 & 0 & 0 & 0 & 0 & \cdots & 0 & \cdots & 0 \\
0 & y_{i, 2} & y_{i, 1} & 0 & 0 & 0 & \cdots & 0 & \cdots & 0 \\
0 & 0 & 0 & y_{i, 3} & y_{i, 2} & y_{i, 1} & \cdots & 0 & \cdots & 0 \\
\vdots & \vdots & \vdots & \vdots & \vdots & \vdots & \ddots & 0 & \cdots & 0 \\
0 & 0 & 0 & 0 & 0 & 0 & 0 & y_{i, T-2} & \cdots & y_{i, 1}
\end{array}\right]
$$

このとき，式(9a)のモーメント条件を $N$ 個の観測デー タに当てはめると（標本対応）, 次のように表される.

$$
\frac{1}{N} \sum_{i=1}^{N} \boldsymbol{Q}_{i}^{\prime} \Delta \varepsilon_{i}=0
$$

ここで, $\Delta \varepsilon_{i}=\left(\varepsilon_{i, 3}-\varepsilon_{i, 2}, \varepsilon_{i, 3}-\varepsilon_{i, 2}, \ldots, \varepsilon_{i, T}-\varepsilon_{i, T-1}\right)^{\prime}$ である。

このとき, 操作変数の数とパラメータの数が一致すれ ば丁度識別となり，モーメント条件を連立方程式として 解くことでパラメータの推定值を得ることができる．し かし, 差分一般化積率法のように操作変数の数が多く, パラメータの数と一致することがない場合には，連立方 程式をすべて満たす解は存在しない，そこで，以下の評 価関数を最小化することによってパラメータの一致推定 量を得ることができる22.

$$
\min J_{N}=\left(\frac{1}{N} \sum_{i=1}^{N} \boldsymbol{Q}_{i}^{\prime} \Delta \varepsilon_{i}\right) \boldsymbol{W}_{N}\left(\frac{1}{N} \sum_{i=1}^{N} \boldsymbol{Q}_{i} \Delta \boldsymbol{\varepsilon}_{i}^{\prime}\right)
$$

ここで， $\boldsymbol{W}_{N}$ : 半正定な加重行列（後述）である.

\section{（2）システムー般化積率法 (System-GMM)}

差分一般化積率法では式 (8)の 1 階差分式を推計式と して用いている．そのため，説明・被説明変数が強い系 列相関をつ場合（例えば変数が単位根に近い性質を持つ ような場合）には，差分を取る前の基本式に比べて説 明・被説明変数間の相関が弱まる可能性が危惧される.

システム一般化積率法を用いることで，このような潜 在的バイアスと差分推計量の不正確性を減らすことがで きる.これは，1階差分式と当初の基本式を統合利用す ることで操作変数の数を増やし，それらを同時に考慮し た以下のモーメント条件より推定值を得る方法である.

$$
\begin{gathered}
E\left[\left(y_{i, t-1}-y_{i, t-2}\right) \cdot\left(\varphi_{i}+\varepsilon_{i t}\right)\right]=0 \quad \forall t=3, \ldots, T \\
E\left[\left(\boldsymbol{V}_{i, t-1}-\boldsymbol{V}_{i, t-2}\right) \cdot\left(\varphi_{i}+\varepsilon_{i t}\right)\right]=\mathbf{0} \quad \forall t=3, \ldots, T
\end{gathered}
$$

このとき, 以下の新たな操作変数行列 $\boldsymbol{Q}_{i}^{+}$を定義する.

$$
\boldsymbol{Q}_{i}^{+}=\left[\begin{array}{ccccc}
\boldsymbol{Q}_{i} & \mathbf{0} & \mathbf{0} & \cdots & \mathbf{0} \\
\mathbf{0}^{\prime} & \Delta y_{i, 2} & 0 & \cdots & 0 \\
\mathbf{0}^{\prime} & 0 & \Delta y_{i, 3} & \cdots & 0 \\
\vdots & \vdots & \vdots & \ddots & 0 \\
\mathbf{0}^{\prime} & 0 & 0 & \cdots & \Delta y_{i, T-1}
\end{array}\right]
$$

ここで， $\Delta y_{i, t} \equiv y_{i, t}-y_{i, t-1}$ である．また， $\boldsymbol{Q}_{i}$ は差分一 般化積率法で用いられる操作変数行列(式(10)) である.

$\boldsymbol{Q}_{i}^{+}$では, $\boldsymbol{Q}_{i}$ に加えて追加的な操作变数 $\Delta y_{i, t}$ を導入して いる. この $\boldsymbol{Q}_{i}$ を式(7)と式(8)の連立方程式に適用し, 差 分一般化積率法と同様の方法 (モーメント条件式(11)と 評価関数式(12)に相当するもの) を用いることで，パラ メータの一致推定量を得ることができる.

システム一般化積率法では, 原理上, パネルデータの 全時系列に対して操作変数を定義することが可能である. しかし，今回の分析データのようにクロスセクションの サンプル数（国数）が大きくない場合には過剩識別バイ アスが発生しや寸いため，より少ないモーメント条件を 適用することが望ましい，そこで本研究では，モーメン 卜条件を制約するために 2 段階システム一般化積率法を 適用寸る. 前述の荷重行列の中でも最も単純なものは,

$$
\boldsymbol{W}_{N}^{1}=\left(\frac{1}{N} \sum_{i=1}^{N}\left(\boldsymbol{Q}_{i}^{\prime} \boldsymbol{H} \boldsymbol{Q}_{i}\right)\right)^{-1}
$$

と表される.ここで,

$$
\boldsymbol{H}=\left[\begin{array}{cccccc}
2 & -1 & 0 & 0 & \cdots & 0 \\
-1 & 2 & -1 & 0 & \cdots & 0 \\
0 & -1 & 2 & -1 & \ldots & 0 \\
0 & 0 & -1 & 2 & \ddots & 0 \\
\vdots & \vdots & \vdots & \ddots & \ddots & -1 \\
0 & 0 & 0 & 0 & -1 & 2
\end{array}\right]
$$

である。このウェイト行列を利用して得られる推定量は 1 段階 GMM 推定量と呼ばれる ${ }^{28}$. 但し，これは一致推 定量であるものの必ずしも漸近効率的ではなく，さらに， 不均一分散の場合にはパラメータの標準誤差の推定量は 一致推定量とならない. White ${ }^{29)}$ に準じてロバストな標 準誤差を用いる必要があり, それは次式で与えられる.

$$
\boldsymbol{W}_{N}^{*}=\left(\frac{1}{N} \sum_{i=1}^{N}\left(\boldsymbol{Q}_{i}^{+\prime} \Delta \hat{\boldsymbol{\varepsilon}}_{i} \Delta \hat{\boldsymbol{\varepsilon}}_{i}^{\prime} \boldsymbol{Q}_{i}^{+}\right)\right)^{-1}
$$

ここで, $\Delta \hat{\varepsilon}_{i}$ は上述の 1 段階 $\mathrm{GMM}$ 推定量によって得ら れた誤差項の推定值 (残差) である.

こうして得られた加重行列 $\boldsymbol{W}_{N}^{*}$ を用いて評価関数最小 化基準のもとで得られる推定量を 2 段階 GMM 推定量と 言い，本研究でもこの方法を用いる．また，このロバス 卜標準偏差で推定值を除すことにより，ロバスト $\mathrm{t}$ 值を 得ることができる. 


\section{(3) 統計的検定}

2 段階 GMM 推定から得られる推定結果が一致性を持 つかどうかを判定するために，様々な検定方法が提案さ れている. 本研究では, 次の二つの方法を採用する.

2 段階 GMM 推定量において, 操作変数の選び方が推 定結果に大きな影響を与えることは明らかである。そこ で一つ目の検定として, Hansen の過剩識別制限検定 ${ }^{23}$ を 行う.この検定では, 操作変数の妥当性を判定すること ができ，帰無仮説を棄却されない場合にそのモデルが支 持される.

二つ目は Arellano-Bond 検定 ${ }^{22)}$ と呼ばれるもので，攪乱 項の自己相関（Auto-Regressive: AR）の程度を調べること ができる. システム一般化積率法は，操作変数として過 去の被説明変数を用いるため，攪乱項に自己相関がある 場合には一致推定量が得られない．このテストでも帰無 仮説が棄却されない場合にそのモデルが支持される.

\section{注}

[1] 例えば東日本大震災の場合, 復興特別法人税は平成 24 年度 27 年度の 3 年間の事業に対し課税される措置 となっており，一期を 5 年とする本研究の枠組みでは, 大規模自然災害発生と経済政策としての対応が同一 期間内で完結していることから，課税の影響は推定 結果に適切に反映されると考えることができる。一 方, 復興特別所得税については, 課税期間が平成 25 年当初〜平成49年末（予定）と長期間に渡るため, その影響を反映するためには，政策ダミ一変数等を 新たに導入するなどの追加的対応が必要となる.

[2] Noy ${ }^{5)}$ では, 経済被害額がGDP成長率に対して有意な 正の影響を与えており，統計的に有意でなかった本 研究とは結論が異なっている，その理由として，本 研究の推定被害額には直接被害額と間接被害額の療 法が含まれるのに対し，Noy (5゙は直接被害額のみし か考慮していないことが考えられる.

\section{参考文献}

1) 内閣府：http://www5.cao.go.jp/j-j/cr/cr11/chr11020201. $\mathrm{html}$

2) 永松伸吾: 経済発展と災害一Uカーブ現象の理論的考 察, 地域安全学会論文集, Vol. 6, pp. 341-346, 2004.

3) Albala-Bertrand, J. M. : Natural disaster situation and growth: A macroeconomic model for sudden disaster impact, World Development, Vol. 21, pp. 1417-1434, 1993.

4) Raddatz, C. : External shock responsible for the instability of output in low-income countries?, Journal of Development Economics, Vol. 84, pp. 155-187, 2007.

5) Noy, I. : The macroeconomic consequences of disasters, Journal of Development Economics, Vol. 88, pp. 221-231, 2009.

6) Loayza, N. V., Olaberria, E., Rigolini, J. and Christensen,
L. : Natural disasters and growth: Going beyond the averages, World Development, Vol. 40, pp. 1317-1336, 2012.

7) 戸堂康之：日本経済の底力〜卧龍が目覚めるとき〜, 中公新書, 2011.

8) Skidmore, M. and Toya, H. : Do natural disasters promote long-run growth?, Economic Inquiry, Vol. 40, pp. 664-687, 2002.

9) Noy, I. and Aekkanush, N. : What do exogenous shock tell us about growth theories?, Working paper, Santa Cruz Center for International Economics, No. 07-16, 2007.

10) Cuaresma, J. C., Hlouskova, J. and Obersteiner, M. : Natural disaster as creative destruction? Evidence from developing countries, Economic Inquiry, Vol. 46, pp. 214-226, 2008.

11) Fomby, T., Ikeda, Y. and Loayza, N. V. : The growth aftermath of natural disasters, Journal of Applied Econometrics, Vol. 28, pp. 412-434, 2013.

12) Raddatz, C. : The wrath of god: Macroeconomic costs of natural disasters, Policy Research Working Paper, The World Bank, No. 5039, pp. 1-35, 2009.

13) 外谷英樹：自然災害のマクロ経済への長期的インパ クトについて，澤田康幸(編) 巨大災害・リスクと経 済, pp. 79-102, 日本経済新聞出版社, 2014.

14) World Bank World Development Indicators 2012, Washington, D. C.: World Bank, 2012, http://data.worldbank.org /data-catalog/world-development-indicators/

15) Centre for Research on the Epidemiology of Disasters Emergency Disasters Database (EM-DAT), Katholieke Universiteit Leuven: Bergium, 2013, http://www.emdat.be/

16) Kahn, M. E. : The death toll from natural disasters: The role of income, geography and institutions, Review of Economics and Statistics, Vol. 87, pp. 271-284, 2005.

17) IMF : Fund assistance for countries facing exogenous shocks, Policy Development and Review Department, Washington, D. C.: International Monetary Fund, 2003.

18) Durlauf, S. N., Johnson, P. A. and Temple, J. R. W. : Growth Econometrics, In P. Aghion and S. N. Durlauf (eds.) Handbook of Economic Growth, Elsevier, Vol. 1, pp. 555-677, 2005.

19) Barro, R. J. : Economic growth in a cross section of countries, Quarterly Journal of Economics, Vol. 106, pp. 407443, 1991.

20) Arellano, M. and Bover, O. : Another look at the instrumental variable estimation of error-components model, Journal of Econometrics, Vol. 68, pp. 29-52, 1995.

21) Blundell, R. and Bond, S. : Initial conditions and moment restrictions in dynamic panel data models, Journal of Econometrics, Vol. 87, pp. 115-143, 1998.

22) Arellano, M. and Bond, S. : Some tests of specification for panel data: Monte Carlo evidence and an application to employment equations, Review of Economic Studies, Vol. 58, pp. 277-297, 1991.

23) Hansen, L. P. : Large sample properties of generalized method of moments estimators, Econometrica, Vol. 64, pp. 1029-1054, 1982.

24) Okuyama, Y. : Economics of natural disasters: A critical review, Paper presented at at the 50th North American Meeting, Regional Science Association International, 2003.

25) Hallegatte, S. and Dumas, P. : Can natural disasters have positive consequences? Investigating the role of embodied 
technical change, Ecological Economics, Vol. 68, pp. 777786, 2009

26) Mankiw, G., Romer, D. and Weil, D. N. : A contribution to the empirics of economic growth, Quarterly Journal of Economics, Vol. 107, pp. 407-437, 1992.

27) 北村行伸：パネルデータ分析, 岩波書店, 2005.

28) 戸堂康之：技術伝播と経済成長〜グローバル化時代
の途上国経済分析～，勁草書房，2008.

29) White, H. : A heteroskedasticity-consistent covariance matrix estimator and a direct test for heteroskedasticity, Econometrica, Vol. 48, pp. 817-838, 1980.

(2016. 2. 26 受付)

\section{INVESTIGATING THE RELATION BETWEEN NATURAL DISASTERS AND ECONOMIC GROWTH USING CROSS-COUNTRY AND SECTOR-BASED MACROECONOMIC DATA}

\section{Daisuke FUKUDA and So-ichiro ENDO}

This study examined the causal relationship between natural disasters and economic growth. We set up an econometric model to analyze cross-country and sector-based macroeconomic data jointly with several indices of natural disasters. We found that i) natural disasters may affect GDP growth positively but not statically significant; ii) for the growth of each economic sector the effect of natural disaster would be different. Furthermore, we found that major estimation results would be consistent with the hypothesis called "Productivity Effect of Natural Disasters" proposed by past theoretical studies. 